\title{
Control of powdery mildew on glasshouse-grown roses and tomatoes in the Netherlands using anhydrous milk fat and soybean oil emulsions
}

\author{
K.V. Wurms ${ }^{1}$ and J.D. Hofland-Zijlstra ${ }^{2}$ \\ ${ }^{1}$ The New Zealand Institute for Plant E Food Research Limited, Private Bag 3230, \\ Hamilton, New Zealand \\ ${ }^{2}$ Wageningen UR Greenhouse Horticulture, Post box 20, 2665 ZG Bleiswijk, \\ The Netherlands \\ Corresponding author: kirstin.wurms@plantandfood.co.nz
}

\begin{abstract}
Powdery mildew (PM) is a very serious disease affecting glasshouse-grown roses and tomatoes in the Netherlands. Control is limited because of resistance to existing fungicides. Anhydrous milk fat (AMF) and soybean oil (SBO) emulsions were evaluated for control of PM in roses and tomatoes. Both AMF (14 g/litre) and SBO (14 g/litre) provided powdery mildew control on rose leaves and blooms that was significantly better $(\mathrm{P}<0.001)$ than that achieved using formulated dodemorph acetate $(2.5 \mathrm{ml} /$ litre $)$, a systemic fungicide commonly used by Dutch rose growers. Powdery mildew control with SBO was as good as that provided by dodemorph acetate on tomato fruit and flowers, while AMF was slightly less effective. Combination of SBO (3.5 g/litre) and AMF (3.5 g/litre) mostly provided PM control rivalling that of SBO (14 g/litre). Spraying roses with whole milk $(20 \% \mathrm{v} / \mathrm{v})$ left white residues. No evidence of phytotoxicity with the use of natural product emulsions was found on floral and fruit tissues.
\end{abstract}

Keywords anhydrous milk fat, soybean oil, biopesticides, natural products, powdery mildew, glasshouse roses, tomatoes.

\section{INTRODUCTION}

Powdery mildew (PM), which is one of the most ubiquitous and serious global diseases of cucurbit, apple, rose, grape and cereal crops (Glawe 2008), is caused by a range of pathogens on different plant hosts. This disease is particularly prevalent in glasshouse production, where dense planting and favourable environmental conditions quickly lead to disease epidemics if left unchecked. The continental climate of the Netherlands dictates that much of the production of high-value crops such as tomatoes and roses is carried out indoors.
Intensive use of synthetic fungicides has led to resistance development to many of the key chemistries used for PM control, such as dimethyl inhibitors (DMIs) (McGrath 2001; Gao et al. 2009) and severe restrictions on the use of others, e.g. strobilurins, now known as QoIs (Beresford 2005). Problems with existing controls, together with increasing concerns about effects on human health and the environment, have increased the push to develop more natural alternatives. These can be used as standalone products, or 
in integrated disease control programmes, to reduce the application number of traditional synthetic pesticides.

The concept that fats and oils can provide effective disease control of horticultural pathogens is not novel (Kabara 1978, 1984; McGrath \& Shishkiff 1999). However, many problems are associated with use of lipids in biopesticides, including handling and application difficulties, spoilage and development of unpleasant odours, phytotoxicity, and unwanted growth of nontarget organisms. These considerations restrict practical applications. Research programmes have aimed to provide natural fat/oil-based fungicides that overcome or ameliorate the problems described above. For example, two biopesticides have been formulated based on emulsified anhydrous milk fat (AMF) from cows' milk and emulsified soybean oil (SBO) that are effective against several PM pathogens and Botrytis cinerea, and provide disease control equalling that of traditional synthetic fungicides (Ah Chee et al. 2011; Wurms \& Ah Chee 2011; Wurms et al. 2011). A commercial preparation of SBO (MIDI-Zen ${ }^{\circledR}$, produced by Botry-Zen 2010 Ltd, Dunedin) is sold in New Zealand for control of Botrytis cinerea and powdery mildew on grapes.

One major caveat of the use of emulsified AMF and SBO is that they are non-systemic and have contact-only activity. Hence they can only be applied in situations where target sites are easily accessible, such as plantings of high-value crops trained up supports in glasshouses, rather than in situations where prostrate growth habits are not restrained in any way resulting in multilayer leaf canopies, e.g. field-grown squash (K.V. Wurms, unpublished data). Roses and tomatoes are high-value crops grown widely in glasshouses in worldwide markets, and initial research has shown that AMF and $\mathrm{SBO}$ are active against the rose PM pathogen, Sphaerotheca pannosa var. rosae (Ah Chee et al. 2011), on leaf tissue, but evidence for control of the tomato PM pathogen, Oidium neolycopersici, is largely anecdotal. It is not known whether AMF and SBO can be used without damaging sensitive floral or fruit tissues. These questions are the objective of this research, which may facilitate uptake of these biopesticides into lucrative global markets.

\section{MATERIALS AND METHODS Artificial inoculation}

All plant material was artificially inoculated with a $1 \times 10^{3}$ spores $/ \mathrm{ml}$ suspension of powdery mildew, using a spray bottle to cover the surface with a fine mist. For all experiments on 'Red Naomi' rose leaves and blooms, and 'Snacker' tomato leaves and fruit, inoculation took place approximately $2 \mathrm{~h}$ before treatment application. Preparation of PM inoculum was the same for each experiment. Sterile, deionised water $(25 \mathrm{ml})$ was placed into a $50 \mathrm{ml}$ Falcon tube along with as many powdery mildew infected leaves from the appropriate plant material that could fit into the tube. Infected rose leaves were used for the rose experiments and infected tomato leaves for the tomato experiments. The Falcon tube was then shaken for 20 s. After removal of the leaves, the liquid was decanted into a beaker. This whole process was repeated five times and then two drops of Tween ${ }^{\circledR} 20$ were added to the liquid. A haemocytometer was used to perform spore counts and the concentration of the suspension adjusted with water to $1 \times 10^{3}$ spores $/ \mathrm{ml}$. Spore suspensions were used within $1 \mathrm{~h}$ of preparation.

\section{Treatment application and disease assessments}

The same 10 treatments (Table 1) were applied in all four experiments to artificially inoculated plant material. Treatments containing emulsified AMF and SBO were made up in advance as 25-fold concentrates, and were diluted with tap water by mixing $40 \mathrm{ml}$ of concentrate with $960 \mathrm{ml}$ of water immediately before use. The Fungicide and Milk+BP treatments were made up freshly on the day of treatment application. In the Netherlands, a fungicide containing dodemorph acetate as the active ingredient (sold as Meltatox $400 \mathrm{EC}^{\circledR}$ ) is permitted for the treatment of powdery mildew on roses only, but was used as a reference chemical for the experiments on 'Snacker' tomatoes. Treatments were applied using hand-held spray bottles, with products applied to provide complete and thorough coverage of all appropriate plant surfaces. 
Table 1 Treatments applied to 'Red Naomi' roses and 'Snacker' tomatoes that had been artificially inoculated with powdery mildew.

\begin{tabular}{|c|c|c|}
\hline Treatment & Treatment code & Rate \\
\hline Untreated control & Untreated & \\
\hline Tap water-sprayed control & Water & \\
\hline $\begin{array}{l}\text { Dodemorph acetate }+ \\
\text { formulation ingredients }\end{array}$ & Fungicide & $2.5 \mathrm{ml} /$ litre \\
\hline Whole milk $+\mathrm{BP}^{1}$ & Milk+BP & Milk 200 ml/litre; BP 20 ml/litre \\
\hline $\mathrm{AMF}^{2}$ & AMF-14 & $14 \mathrm{~g} /$ litre \\
\hline AMF & AMF-7 & $7 \mathrm{~g} /$ litre \\
\hline AMF & AMF-3.5 & $3.5 \mathrm{~g} /$ litre \\
\hline $\mathrm{AMF}+\mathrm{BP}$ & AMF-14+BP & AMF 14 g/litre; BP 20 ml/litre \\
\hline $\mathrm{SBO}^{3}$ & SBO-14 & $14 \mathrm{~g} /$ litre \\
\hline $\mathrm{AMF}+\mathrm{SBO}$ & AMF-3.5/SBO-3.5 & AMF 3.5 g/litre; SBO 3.5 g/litre \\
\hline \multicolumn{3}{|c|}{$\begin{array}{l}{ }^{1} \text { Yakult }{ }^{\circledR} \text { is a commercially-available probiotic fermented drink containing Lactobacillus casei, and } \\
\text { is code-named bacterial product (BP) in this study. This has been shown to have antifungal activity } \\
\text { against PM when used in combination with milk (Zatarim et al. 2005). } \\
{ }^{2} \text { Emulsified anhydrous milk fat (AMF) was sourced from Royal VIV Buisman, Wijk en Aalburg, the Netherlands. } \\
{ }^{3} \text { Emulsified soybean oil (SBO). }\end{array}$} \\
\hline
\end{tabular}

Assessments of PM disease severity in the rose leaf and flower experiments and the tomato leaf trial were based on the following disease rating scale (from Spencer (1977): $0=$ No infection, $1=\leq 1 \%$ infection, $2=2-5 \%$ infection, $3=6-20 \%$ infection, $4=21-40 \%$ infection, $5=>$ $40 \%$ infection and $6=100 \%$ infection.

\section{Rose leaf and flower experiments}

Disease free, glasshouse-grown export-grade single stem 'Red Naomi' roses, with fully open flowers, were obtained from a local grower on the morning of the trial. Stem ends were cut with secateurs under water to approximately $60 \mathrm{~cm}$ in length, and were placed into individual jars, each containing $600 \mathrm{ml}$ of tap water. Plant material was artificially inoculated with PM by spraying the adaxial and abaxial surfaces of both leaves and petals with a fine mist of the prepared spore suspension. Droplet size was adjusted to prevent run-off. After $2 \mathrm{~h}$ drying in the glasshouse $(70 \%$ relative humidity $(\mathrm{RH})$, $20^{\circ} \mathrm{C}, 12 \mathrm{~h}$ photoperiod), treatments (Table 1) were applied using hand-held bottles. There were eight replicates per treatment, with each replicate comprising a single stem for each treatment, placed on a different table in the greenhouse. A second treatment application was made 7 days later. Assessments of PM disease severity took place 3 weeks after the initial treatment application. For the rose leaf experiment, the disease rating was given as an overall average for all 3-4 compound leaves on the cut stem.

\section{Tomato leaf experiment}

Disease-free leaves of approximately the same size were collected from 10 mature 'Snacker' tomato plants growing in the glasshouse. The leaves were surface sterilised by first rinsing for $7 \mathrm{~min}$ in sterile demineralised water followed by rinsing for $2 \mathrm{~min}$ in $0.45 \% \mathrm{v} / \mathrm{v}$ household bleach and then three lots of 2-min rinses in tap water. After this, the leaves were placed on sterile paper to remove excess water. Whilst the leaves were drying, autoclaved water agar ( $15 \mathrm{~g} /$ litre) was prepared and poured into vented Petri dishes. Once the agar had cooled to $30-35^{\circ} \mathrm{C}$, a single leaf was placed onto the agar into each Petri dish, the lid replaced and the agar allowed to set fully overnight. On the following morning, the leaves were inoculated with PM spore suspension by misting the exposed leaf surface to obtain complete coverage, with the 
spray bottle held about $20 \mathrm{~cm}$ above each plate. Test products were applied $2 \mathrm{~h}$ later using spray bottles to apply a light misting to the entire adaxial surface of each leaf. There were 10 replicate Petri dishes, each containing a single leaf from a different plant, for each treatment. The plates were organised in blocks in the controlled environment (CE) room $\left(70 \% \mathrm{RH}, 20^{\circ} \mathrm{C}, 12 \mathrm{~h}\right.$ photoperiod) for the duration of the experiment. The experimental set-up was a completely randomised block design, with one of each treatment per block. An additional treatment application was made 5 days after the initial application. PM disease assessment was carried out 8 and 14 days after the initial treatment application. Only the results from the final disease assessment are presented here.

\section{Tomato fruit experiment}

Disease-free mature fruit of similar size were collected from different 'Snacker' tomato plants growing in the glasshouse. Fruit were surface sterilised as described in the tomato leaf experiment, and then cut into halves using aseptic technique and placed cut-side down into plastic containers with clear lids. There were three rows of tomatoes in each container - each row contained the two halves of a single tomato, and the tomato halves in each row came from a different plant. Inoculation and initial treatment application were the same as described for the tomato leaf experiment. Holes allowing for gaseous exchange were placed in the lid of every container using a heated needle. One container per treatment was placed in each of five different blocks in the CE room. Disease assessment was carried out 3 days after the initial treatment application, using an arbitrary scale as follows: $1=$ fruit perfectly healthy, 2 = fruit has discoloured oozing, but no obvious signs of fungal growth, 3 = fungal growth around cut edges, and $4=$ Fungal growth on cut edges and other parts of fruit and/ or ooze or severe infection. The source of infection was not distinguished in this scale.

Although a second treatment application was made 4 days after the initial treatment, followed by a second disease assessment 7 days after initial treatment, the fruit were too rotten for these data to be usable.

\section{Statistical analysis}

Disease severity scores were converted into quantitative percent infection values, by taking the mid-point of the infection range corresponding to each severity score. The severity score for the tomato fruit experiment was not able to be converted into percentage infection, and therefore was analysed as is. Treatment differences were analysed using a randomised block design (RBD) by analysis of variance (ANOVA), with means separation by Fisher's Least Significant Difference (LSD) $(\mathrm{P}<0.05)$, using Genstat $16^{\text {th }}$ Edition.

\section{RESULTS \\ Rose leaf and flower experiments}

The Milk+BP and all of the AMF and SBO treatments significantly reduced PM severity on rose leaves, relative to the Water and Untreated negative controls, and to the Fungicide positive control treatment $(\mathrm{P}<0.001$, Figure 1). Although the Milk+BP, AMF and SBO treatments were not significantly different to each other, the lowest rate of AMF (3.5 g/litre) resulted in higher PM leaf infection, unless combined with an equivalent quantity of SBO, as seen in the AMF-3.5/SBO-3.5 treatment, and the SBO-14 treatment (14 g/litre) produced the lowest infection of all the treatments (Figure 1). It was also observed that the leaves of the SBO treatment were more shiny compared to the other treatments and remained firm without shrivelling (data not shown).

PM infection was slightly higher on the blooms than on leaves (Figure $1 \mathrm{cf}$. Figure 2). Floral infection was highest in the Untreated and Water treatments followed by the Fungicide treatment (Figure 2). Whilst all other treatments reduced the severity of PM infection, only the reductions in the AMF-14, SBO-14 and AMF-3.5/SBO-3.5 treatments were significant, compared with the Untreated and Water treatments $(\mathrm{P}<0.001$, Figure 1). The Milk+BP treatment left a white residue on leaves and blooms, but not the treatments containing AMF and SBO (Figure 3).

\section{Tomato leaf experiment}

Tomato PM leaf infection was highest in the Untreated and Water treatments, and lower 


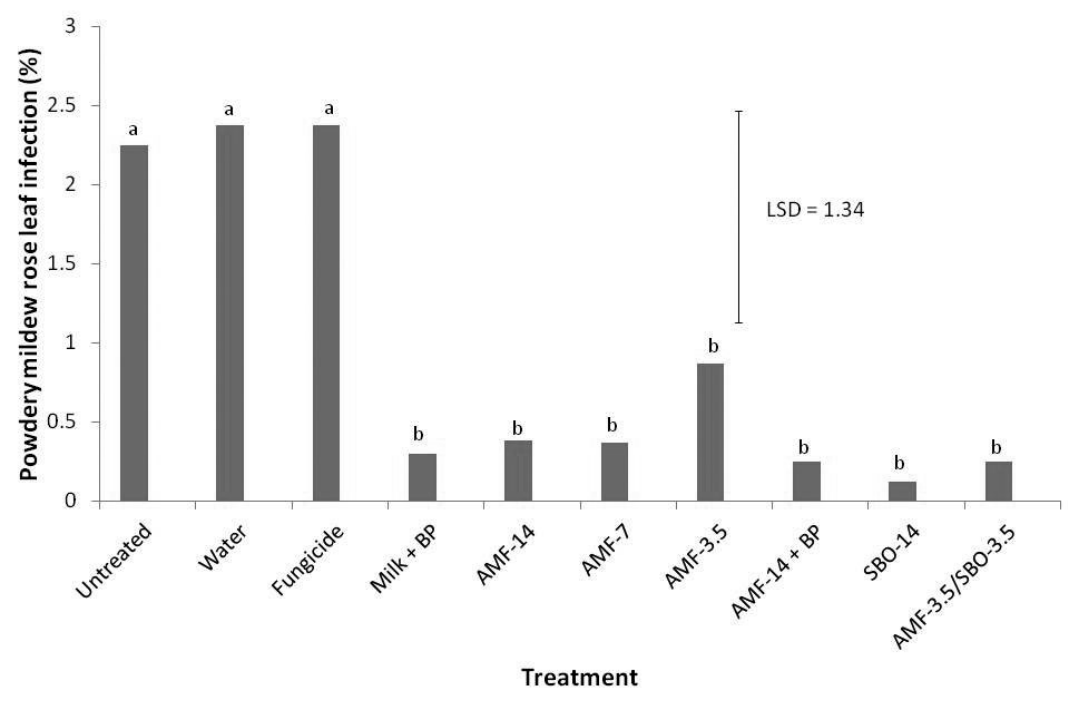

Figure 1 Mean percentage of powdery mildew infection on 'Red Naomi' rose leaves on single cut stems, assessed 21 days after artificial inoculation of all leaf material with $1 \times 10^{3}$ spores $/ \mathrm{ml}$ of Sphaerotheca pannosa var. rosae. The initial treatment application followed $2 \mathrm{~h}$ after artificial inoculation, when plant material was completely dry, and a second treatment spray 7 days later. Treatments and statistical analysis are described in full in the methods.

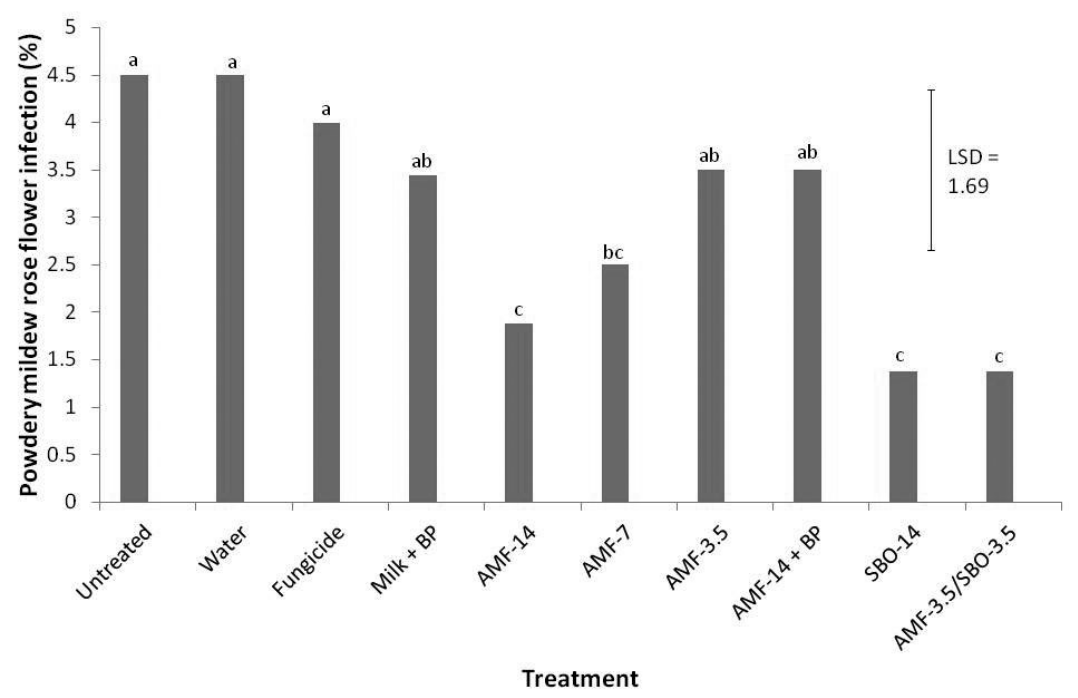

Figure 2 Mean percentage of powdery mildew infection on 'Red Naomi' rose blooms on single cut stems, assessed 21 days after artificial inoculation of all leaf material with $1 \times 10^{3}$ spores $/ \mathrm{ml}$ of Sphaerotheca pannosa var. rosae. The initial treatment application followed $2 \mathrm{~h}$ after artificial inoculation, when plant material was completely dry, and a second treatment spray 7 days later. Treatments and statistical analysis are described in full in the methods. 


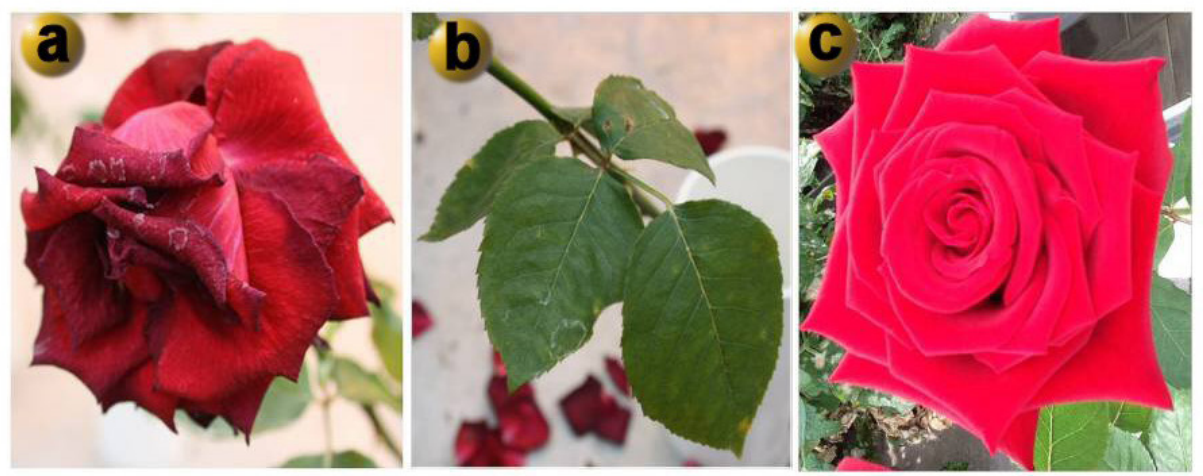

Figure 3 White-coloured milk spray residue (200 ml/litre whole milk) on (a) a 'Red Naomi' rose bloom and (b) leaf, compared with (c) residue-free tissue sprayed with anhydrous milk fat (14 g/litre).

in all other treatments $(\mathrm{P}<0.001$, Figure 4). However, only the SBO-14 and AMF-3.5/SBO3.5 treatments provided PM control as good as the Fungicide treatment $(\mathrm{P}<0.001$, Figure 4$)$.

\section{Tomato fruit experiment}

The tomato fruit rotted more quickly than any of the other detached plant tissues tested. Figure 5 shows that disease severity was highest in the Water treatment followed by the Untreated and Milk+BP treatments. All other treatments had lower disease severity scores, but only the reductions in the Fungicide, AMF-14+BP, SBO-14 and AMF-3.5/ SBO-3.5 treatments were significant, compared with the three worst treatments $(\mathrm{P}<0.001$, Figure 5). The SBO-14 and AMF-14 treatments did not cause any phytotoxicity or leave residues on the fruit (data not shown).

\section{DISCUSSION}

The results of these trials demonstrate that AMF and SBO can provide control of PM in detached shoots, leaves and fruits of tomato and detached shoots and blooms of roses, which equals or betters that of conventional fungicides, without damaging sensitive tissues.

In the experiments on rose leaves and blooms, all treatments containing AMF or SBO provided significantly better control $(\mathrm{P}<0.001)$ than the Unsprayed and Water negative control treatments. Whilst Figures 1 and 2 show that none of the AMF and SBO treatments were significantly different from each other, PM infections were approximately twice as high when $3.5 \mathrm{~g} /$ litre of AMF was used, compared with $14 \mathrm{~g} /$ litre of AMF, indicating that the amount of active ingredient is important. PM infection was lowest in the SBO-14 treatment on both leaves and blooms. These observations confirm the findings of Ah Chee et al. (2011), who observed that AMF and SBO both provided effective control of PM on 'Sahara' rose leaves, and that SBO gave slightly better control than AMF, although differences were not statistically significant. The fungicide treatment in the current study was intended to be a positive control, but PM levels on pesticide-treated blooms and leaves were as high as the negative controls. This suggests that Sphaerotheca pannosa var. rosae resistance to this pesticide may be occurring in the Netherlands. Dodemorph acetate is used very intensively by local rose growers, with the largest grower of 'Red Naomi' roses in the Netherlands applying this fungicide in combination with a strobilurin containing kresoxim-methyl + boscalid on a weekly basis (Aad van Luijk, Porta Nova, the Netherlands, personal communication). This emphasises the need for new chemistries and alternative control products. Resistance strategies and integrated pest management programmes should also be implemented for future use of this fungicide to maximise its longevity.

Treatments containing SBO and AMF also significantly reduced PM infection on tomato leaves and fruit, with the most effective treatments, SBO-14 and AMF-3.5/SBO-3.5, 


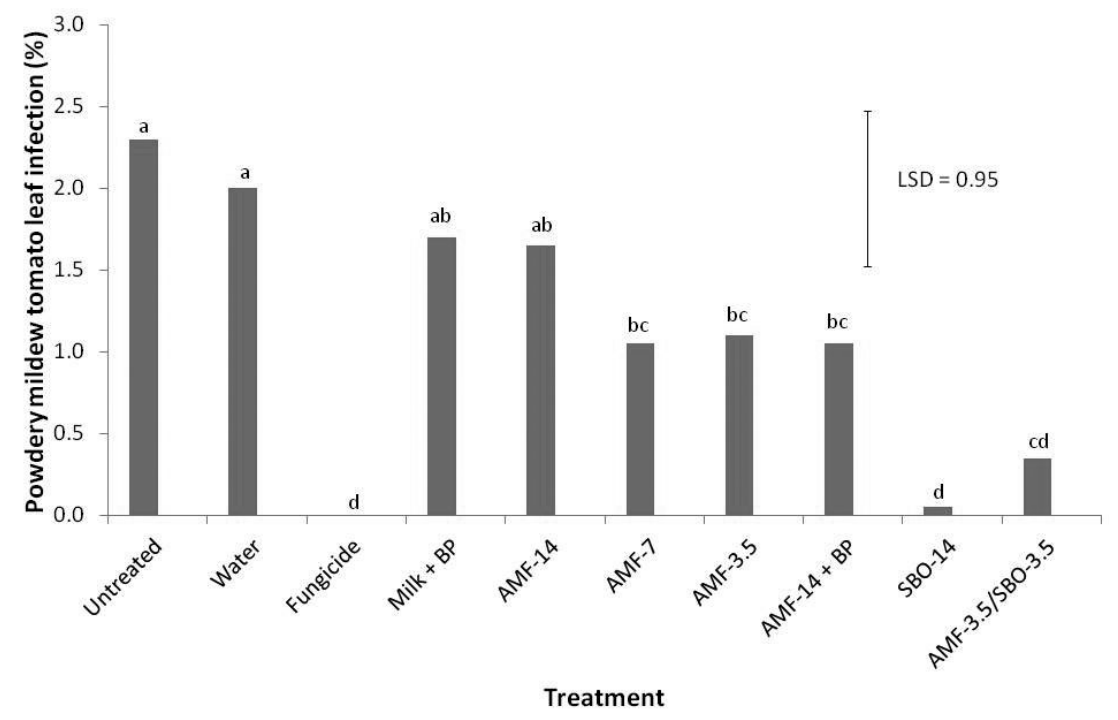

Figure 4 Mean percentage of powdery mildew infection on 'Snacker' tomato leaves, assessed 26 days after artificial inoculation of all leaves with $1 \times 10^{3}$ spores $/ \mathrm{ml}$ of Oidium neolycopersici. The initial treatment application followed $2 \mathrm{~h}$ after artificial inoculation, with an additional treatment application made 5 days after the initial application. Treatments and statistical analysis are described in full in the methods.

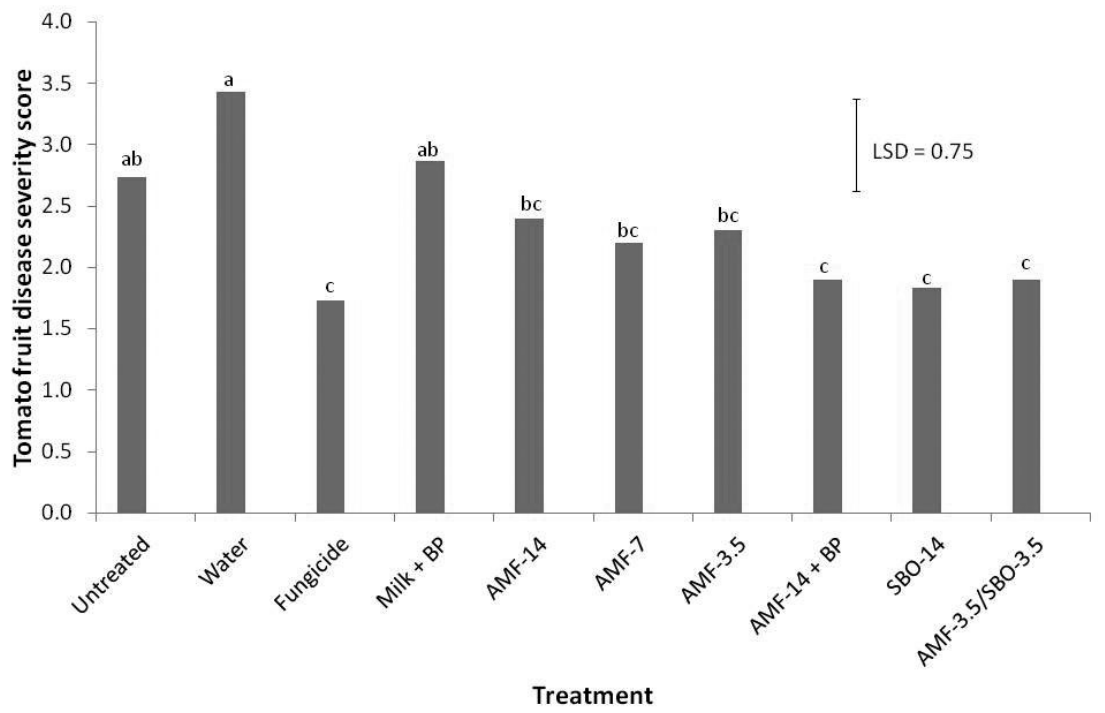

Figure 5 Disease severity score on 'Snacker' tomato fruit, assessed 3 days after artificial inoculation of all leaves with $1 \times 10^{3}$ spores $/ \mathrm{ml}$ of Oidium neolycopersici. The arbitrary severity score was defined as follows: 1 = fruit perfectly healthy; 2 = fruit has discoloured oozing, but no obvious signs of fungal growth; 3 = fungal growth around cut edges (fruit were halved); and $4=$ fungal growth on cut edges and other parts of fruit and/or ooze or severe infection. The initial treatment application followed $2 \mathrm{~h}$ after artificial inoculation. Treatments and statistical analysis are described in full in the methods. 
providing control as good as that provided by dodemorph acetate fungicide. Dodemorph acetate is not used on tomato crops in the Netherlands, but it does show a comparable level of control with other regularly used mildew fungicides on tomatoes such as triflumizole and cyprodinil + fludioxonil. Lack of exposure to dodemorph acetate probably explains why the tomato PM was more sensitive to this fungicide than the rose PM. SBO-14 provided significantly better $(\mathrm{P}<0.001) \mathrm{PM}$ control than AMF-14 on tomato leaves. These results confirm the findings of Ko et al. (2003) that plant oils have antifungal activity against PM on tomato.

The experiments presented here show that combining AMF with SBO had a synergistic effect on PM control on roses and tomatoes. Evidence for this is that the same degree of PM disease control was achieved using $3.5 \mathrm{~g} /$ litre of each product in combination compared with $14 \mathrm{~g} /$ litre of either product on its own. In further support of this argument, use of AMF on its own at $3.5 \mathrm{~g} /$ litre was markedly less effective than AMF at $14 \mathrm{~g} /$ litre. One explanation for synergy might be that AMF and SBO appear to have different modes of action. A scanning electron microscope study carried out on wheat PM after application of AMF and SBO showed that SBO treatment was associated with bursting and release of PM cellular contents, while AMF caused distortion and plasmolysis of fungal structures (K.V. Wurms, unpublished data). Different modes of action may also explain why SBO is more effective than AMF against tomato and rose PM as shown in this study, but the reverse is true for grape PM (Wurms \& Ah Chee 2006).

When using fats and oils, there is often a delicate balance between disease control efficacy and phytotoxicity (Bográn et al. 2015). However, no phytotoxicity associated with use of SBO and AMF was observed, even at the highest concentration of $14 \mathrm{~g} /$ litre. This is in agreement with previous results, where applications of SBO and AMF on roses and apples provided effective control of the powdery mildew pathogen, without phytotoxicity (Ah Chee et al. 2011; Northover \& Schneider 1993; Pasini et al. 1997; Wurms \& Ah Chee 2011).
The Milk+BP treatment gave mixed results, with poor control in the tomato fruit and rose flower assays. Many home gardener websites recommend the use of milk to control PM (Iannotti 2015; Pleasant 2012) and combination with BP has been shown to further boost its PM control efficacy (Zatarim et al. 2005). However, previous observations have shown that application of milk has variable disease control efficacy and PM can quickly develop resistance (Wurms \& Ah Chee 2006), most likely because milk is a mixture of different fats, proteins and carbohydrates, and the PM can utilise some of these ingredients for its own growth. In contrast, AMF, which is derived from milk, contains only the antifungal fat component and no milk sugars or proteins. Hence, it is not surprising that AMF14 provided control that equalled or exceeded that of Milk+BP in all experiments. In addition, the Milk+BP treatment left unsightly residues on all plant tissues, making it unsuitable for use in ornamental crops. AMF-14 also performed as well as or better than AMF-14+BP, indicating that addition of BP did not offer any significant advantage.

This research has provided promising results, but one shortfall of the current study is that it was carried out on excised plant tissue, and therefore only approximates the conditions of whole plants grown in the glasshouse. The next step will be to test these products on whole plants within the glasshouse, where the much higher densities of plant tissue, particularly in a commercial situation, may prove challenging for spray access. Adequate coverage of the plant surfaces requiring protection from PM will be critical to the success of these products, but is achievable, as evidenced by a commercial preparation of SBO (MIDI-Zen $\left.{ }^{\circledR}\right)$ that is already providing the New Zealand grape growers with environmentally friendly and efficacious PM and Botrytis cinerea disease control.

\section{ACKNOWLEDGEMENTS}

The authors wish to give special thanks for the funding from the Trimble Agricultural Research Travel Fellowship that made this research possible. We thank Mike Spiers and Dr Stephen 
Hoyte for valuable editorial comments, and gratefully acknowledge Catherine Cameron of AgResearch, Hamilton, for assistance with statistical analysis.

\section{REFERENCES}

Ah Chee A, Wurms KV, George M 2011. Control of powdery mildew (Sphaerotheca pannosa var, rosae) on rose (Rosa L. sp.) using anhydrous milk fat and soybean emulsions. New Zealand Plant Protection 64: 195-200.

Beresford RM 2005. Qo inhibitor (QoI) management strategy. http://resistance.nzpps. org/index.php? $\mathrm{p}=$ fungicides/qoinhibitor (accessed 31 March 2015).

Bográn CE, Ludwig S, Metz B 2015. Using oils as pesticides. https://insects.tamu.edu/ extension/publications/epubs/e-419.cfm (accessed 8 April 2015).

Gao LQ, Berrie A, Yang JR, Xu XM 2009. Within- and between-orchard variability in the sensitivity of Venturia inaequalis to myclobutanil, a DMI fungicide, in the UK. Pest Management Science 65(11): 1241-1249.

Glawe DA 2008. The powdery mildews: a review of the world's most familiar (yet poorly known) plant pathogens. Annual Review of Phytopathology 46: 27-51 DOI: 10.1146/ annurev.phyto.46.081407.104740.

Iannotti M 2015. How to use milk to control powdery mildew. http://gardening.about. com/od/naturalorganiccontrol/f/How-ToUse-Milk-To-Control-Powdery-Mildew-OnPlants.htm (accessed 8 April 2015).

Kabara J 1978. Fatty acids and derivatives as antimicrobial agents - a review. American Oil Chemists' Society Monograph 5: 1-14.

Kabara J 1984. Antimicrobial agents derived from fatty acids. Journal of the American Oil Chemists' Society 61: 397-403.

Ko WH, Wang SY, Hsieh TF, Ann PJ 2003. Effects of sunflower oil on tomato powdery mildew caused by Oidium neolycopersici. Journal of Phytopathology 151(3): 144-148.

McGrath MT 2001. Fungicide resistance in cucurbit powdery mildew: experiences and challenges. Plant Disease 85(3): 236-245.
McGrath MT, Shiashkiff 1999. Evaluation of biocompatible products for managing cucurbit powdery mildew. Crop Protection 18: 471-478.

Northover J, Schneider KE 1993. Activity of plant oils on diseases caused by Podosphaera leucotricha, Venturia inaequalis, and Albugo occidentalis. Plant Disease 77(2): 152-157.

Pasini C, DAquila F, Curir P, Gullino ML 1997. Effectiveness of antifungal compounds against rose powdery mildew (Sphaerotheca pannosa var. rosae) in glasshouses. Crop Protection 16(3): 251-256.

Pleasant B 2012. Using milk to prevent powdery mildew. http://www.growveg.com/ growblogpost.aspx?id=242 (accessed 8 April 2015).

Spencer DM 1977. Standardized methods for the evaluation of fungicides to control cucumber powdery mildew. In: McFarlane NR ed. Crop protection agents - their biological evaluation. Academic Press, London. Pp. 455-464.

Wurms KV, Ah Chee A 2006. Fungicidal compositions. Patent WO2006006878A1 (also published as NZ534007 and NZ555132, AU2005263039 and AU2011201263, Chile 48.015 and US8349769).

Wurms KV, Ah Chee A 2011. Control of powdery mildew (Podosphaera leucotricha) on apple seedlings using anhydrous milk fat and soybean oil emulsions. New Zealand Plant Protection 64: 201-208.

Wurms K, Ah Chee A, Elmer P, Agnew R, Wood P 2011. Developing new biologically-based products for control of botrytis bunch rot. Part 1: Developing a new natural product for mid-season botrytis control - NP2 moves closer to the market. Wine and Viticulture Journal 26(5): 64-72.

Zatarim M, Cardoso AII, Furtado EL 2005. Efeito de tipos de leite sobre oídio em abóbora plantadas a campo. (English title: Effect of types of cow milk on the powdery mildew control of pumpkin under field conditions.) Horticultura Brasileira 23(2): 198-201. 